\title{
ISLAMISM: EXPRESSION OF POLITICAL ISLAM AND ISLAMIC POLITICS IN SOUTH SULAWESI
}

\author{
Syahrir Karim \\ State Islamic University of Alauddin Makassar \\ Email: sahrirka@gmail.com
}

\begin{abstract}
Islamic politics always plays a key role in the formation of Indonesian national identity even though at certain points Islam had to compromise in the process of establishing the identity. In spite of this, Islam has noticeably brought about strong influence to a major part of Indonesian history. This in turn gives Islam a space to significantly take part in the development of Indonesian politics up to the present time. On the other hand, the role of political parties, particularly those of the Islamic parties, will always shape the discourse of Islamic party in Indonesia. This in turn will be an indicator for the ongoing involvement of Islamic politics in Indonesia, more specifically in South Sulawesi.
\end{abstract}

Key Words: Islamism, Islamic Politics Islamic Party - Indonesian Politics

\section{INTRODUCTION}

The Porch of Medina is a special term or name commonly attached to South Sulawesi. As a matter of fact, given a closer look from historical and political perspectives, 
there is a similarity between Aceh and South Selawesi in terms that they share traces of Islamic empires that are considered very influential in this archipelago. Likewise, during the days of revolution, Aceh and South Sulawesi equally served as the basis for the struggles to establish an Islamic state in Indonesia. Provided that traces of Islam is so strong and deeply rooted in these two areas, Aceh is often referred to as "the Veranda of Mecca" and South Sulawesi is also commonly identified as "the Porch of Medina", for the majority of population in the two areas is Muslim. In fact, the ethnic of Bugis-Makassar is often considered identical with Islam that it is quite normal to presume that a Buginese or Makassarese is definitely a Muslim.

With such a solid Islamic identity, it is quite natural that Islamic symbols are strongly related to their political identities. The expression of Islamic politics and political Islam in South Sulawesi has its own characteristics. This is observable in the fact that a number of Islamic movements in the field of dakwah (Islamic missionary), jihad (religious strive) and politics have helped influence the local political constellation. Political Islamic movements both in the parliament such as PKS, PPP and the United Nations and outside the parliament such as Hizb at-Tahrir, the Committee of Islamic Law Enforcement (KPPSI), Wahdah Islmiyah and many others have contributed their share and hence are highly influential in establishing the identities and the expressions of Islamic politics as well as political Islam on this land of the Porch of Medina. With these existing Islamic political identities, the political expressions of the Bugis-Makassar should directly correspond to the symbols or the Islamic identities they employ. This is what the author means by 'Politik Madani' (Madani Politics), that is, civilized politics that respectfully upholds local values in an Islamic framework.

\section{The phenomenon of Post-Reformation Islamism}

The phenomenon of Islam in Indonesian politics always wins attentions and always makes an interesting topic to discuss. This is presumably because Islam is the religion of the majority in this country, or because the manners of the Islamic 
political actors themselves are specifically unique and interesting to talk about. With various expressions of its adherents, Islam often presents itself not only as a set of teachings but also as an ideology. This situation departs from a religious-political view which refers to the proposition: inna al-Islam al-din wa ad-addawla, which means that Islam is a religion as well as a state. ${ }^{1}$ Although in its development the statement affirming Islam as an ideology is still controversial, in reality, in some Muslim neighborhood there are movements or viewpoints that perceive Islam as an ideology. The controversy is understandable provided that the concept of ideology itself has always been a controversial discourse all along its history, both in terms of a frame of thought and a movement. The view that perceives Islam as an ideology appreciates Islam in the sense of a comprehensive religion comprising all aspects of life including politics and sees into the future of Islam in a straight line or as an integral part of the political and nation state structures. ${ }^{2}$

In the Indonesian context, the above phenomenon occurs in the territory of construction of meaning at the level of implementation of issues and symbols. The Political Islam circles believe that Islam must be realized symbolically in politics, while the substantive Islamic circles are in opposition to the presence of the Islamic party and the symbolization of shari'ah by the State. Islamism is a Western description to provide explanation about the form of Islamic activism that emerged at the first quarter of the 20th century. In its substantial sense, Islamism has four characteristics: first, it supports the rise of Islam as a base for reformation of the society; second, it understands Islam as an ideology; third, it has the aim of establishing an Islamic system or Islamic state (alnizam al-Islami); fourth, it maintains that the characteristic of a

${ }^{1}$ Bahtiar Effendi (2001), Teologi Baru Politik Islam; Pertautan Agama, Negara dan Demokrasi, Yogyakarta, Galang outstanding. p. 29

${ }^{2}$ Islam as an ideology (Islamic Ideology) is founded on a thought that Islam is a universal religion, and this thought is based on the notion viewing Islam as a perfect and absolute principle. 
state or a country's political system is the application of shariah (based on Islamic law). ${ }^{3}$

A different viewpoint defines Islamism as a belief maintaining that Islam has a set of comprehensive and high quality norms or teachings, which could serve as guidelines to preserve a well established social order. ${ }^{4}$ Wherever they settle down, the Islamists always make efforts to replace the existing socio-political rules with the norms or teachings based on certain interpretations of the Islamic teachings. Such efforts are normally pursued through actions of peace campaign or even by violence depending on the value system preserved by the actors of the Islamist movements. Furthermore, Islamism (the political orientation of the Islamists) is crucial in defining the extent of weather a Muslim is considered an Islamist or not. Some experts of Muslim society, such as Lewis and Gellner, or political scientists, such as Huntington and Kedourie, try to prove that Islamism is a universal issue for Muslims. One way to measure Islam is to have an awareness of how the Islamist ideologists define Islam as a socio political ideology. For Bubalo and Fealy, the ultimate goal of Islamism itself is an establishment of a state or an Islamic system. ${ }^{5}$ Nevertheless, the movement of Islamism itself is not monolithic. There are several factions of Islamism but they are similarly aiming at the same objective, which is an establishment of an Islamic state or at least a system based on Islamic ideology.

In the context of Islam, this development has brought about its own assessment, that is, the view on the re-emergence of Islamic political power. This viewpoint is considered

${ }^{3}$ Anthony Bubalo, Greg Fealy \& Whit Mason. 2012. Zealous Democrats: Islamism and Democracy in Egypt, Indonesia and Turkey. Translated by Syamsu Rijal, PKS dan Kembarannya; Bergiat jadi demokrat di Indonesia, Mesir dan Turki. Jakarta, Komunitas Bambu. p.5

${ }^{4}$ Burhanuddin Muhtadi, Dilema PKS; Suara dan Syariah, Gramedia, Jakarta. 2012. p. 48.

${ }^{5}$ Ibid. 
acceptable, provided that one should keep in mind the point that the majority of Indonesian population is Muslim. Directly or indirectly, this fact will bring about some political implications. In other words, the political power of any kind, more specifically a political party, would seriously take into account such demographic reality. It means that the Muslim masses will be contested by the competing political forces in order to obtain support as well as votes, even though in certain regions the articulation (of Islamic political thought) is yet dominated by ideological desire to legitimize the current Islamic society regimes. ${ }^{6}$

On the other hand, the reality in the new era reveals that the emerging political parties comprise not only political parties that support political streams from both the Muslim circles and other social groups, but also organizations or religious movements bearing religious mission and religious symbols, including those of the Muslims. Some of the new and noticeable phenomena that bring about controversy are the actions of some Islamic movements that set up an agenda for the reimplementation of the Jakarta Charter and the application of Islamic law. These movements are commonly identified as radical or fundamental associations, including such as MMI, Hizb at-Tahrir, the Committee of Preparation of Islamic Law Enforcement (KPPSI), and some others from outside of the Islamic political parties that uphold corresponding viewpoints although not as strong as Islamic movements from the militant stream. In pursuing for the application of Islamic law in various areas in South Sulawesi, West Java, as well as in other regions, some of the efforts have been quite successful, to the extent that some of the regions have successfully achieve their own autonomy such as that of Aceh.

In the context of Islamism, the presence of political parties and Islamic organizations featuring Islamic or ideological drift in the era of reformation has openly declared

${ }^{6}$ Bahtiar Effendi (2001), Teologi Baru Politik Islam; Pertautan Agama, Negara dan Demokrasi", Galang Press, Yogyakarta. p. 52. 
and supported the struggle for the reinforcement of Islamic Shariah momentum through the 1945 amendment issue, as pronounced by PPP, PBB, and PK (PKS ) or by KPPSI and Hizb at-Tahrir through political struggles both in the parliamentary and outside of the parliament. They preserve confidence in the authenticity and perfection of Islam with reference to the historical experience of the early generation of Islam. This generation served as the ideological basis for the viewpoints of those who faithfully defend and fight for Islamic sharia as resolutions for the socio-political questions found in the society. The West is thought to have been failed to prosper the sociopolitical order of the world population. In the end the Islamists will always say that "Islamic law is the solution" for a great number of socio political problems existing in the world over the years. Even in the new society those who live around Islamic environment will get pleasure and benefit from knowledge about Islam as it will always provide a way out. ${ }^{7}$ To their view, Islamism is a political movement that violates the modern political concept. Islamism is in a way comparable to Fascism, which has become the enemy of democracy and freedom. ${ }^{8}$

Within the Muslim society environments, in addition to political parties with formal Islamic base as mentioned above, there are also Islamic movements that carry the ideals of the Islamic ideology such as the Council of Indonesian Mujabidin (MMI) and Hizb at-Tahrir Indonesia (HTI), which both take up the struggle for the reinforcement of Islamic law and the Islamic caliphate. Other Islamic movements are such as the Committee of Preparation for Islamic Law Enforcement (KPPSI) in South Sulawesi and other Islamic groups. These

${ }^{7}$ Burhan Ghalioun, (2010), Islamology Comes to Aid of Islamism, DIOGENES 226:120-126

${ }^{8}$ For further explanation, see lihat, Arun Kundnani, Islamism and the Roots Of Liberal Rage, Race Class 2008, Vol. 50(2): 44-45 
Islamic movements, whether engaged directly in the political sphere as political parties or as non political movement with propaganda and ideological drive, have relatively similar ideological traces. To some extent they even have an elite linkage and share perspective with the Islamic movements that carries the idea of an Islamic State or Islam as the principles of the state in the past. This is the core point that gave birth to the tendency of a political oriented Islam that characterizes the resurgence of Islamism and political Islam in the new era that opened the tap of openness to its extraordinary extent. The political situation that develops nowadays greatly affects the existence of the Ideological Islamic movement (Islamism). The climate of openness in the era of reformation provides an opportunity for the Muslim community in particular and public society in general to fight for their aspirations in a very spacious sphere.

\section{Expressions of Political Islam and Islamic Politics in South Sulawesi}

Political Islam is Islam that seeks to be realized and actualized in the realm of power or official political institutions. By referring to Gulalp, Azyumardi Azra also proposes another definition, that is, Islam that appears or is displayed as a frame or base for a political ideology, which then transforms in the form of a political party, or, in Hodgson's term, "Political Islam" is "Islamdom", namely, Islam that is manifested in political power. The term Political Islam is often applied to refer to the category of fundamentalists and neofundamentalists who tend to emphasize the political nature of Islamic features and are directly engaged in anti state activities.?

${ }^{9}$ Nazih N. Ayubi, Political Islam: Religion and Politics in the Arab World (Londres, New York:Routledge, 1993). in Masdar Hilmy, Teologi Perlawanan;Islamisme dan Diskursus di Indonesia Pasca Orde Baru(Yogyakarta:Kanisisus,2009), p.25. 
Such is also the case of the term Islamic Politics. Islamic Politics is in a substance a way of situating Islam to stand in front of the power and the state and, in such a way, gives birth to certain attitudes or political behavior as well as political culture of Islamic value oriented. In a broad sense it is reasonably acceptable to define Islamic Politics as political activities performed by some Muslims who regard Islam as a value reference and as core basis for group solidarity. This is to say that those who take part in these political activities are not necessarily Muslims. In a political category they can be referred to as Islamic politics groups, who also emphasize religious symbolism in running politics, including employment of Islamic symbols as well as Islamic terms for the basic rules of the organizations, the efforts' aim, and the political discourse.

In South Sulawesi, Islam is rendered an important aspect in the government, as Islam is present as the religion of the majority in public life. Up to the present time the people of South Sulawesi are normally identified to be Muslims. Whereas the land of Aceh is well known as the Porch of Mecca, the people of South Sulawesi identified their region as the Porch of Medina. ${ }^{10}$ As a region with a majority of Muslim population, in addition to the existing roots of Islamization that have been surviving there since the days of ancient local kingdoms, it is quite natural that the patterns of Islamism always exist and are significantly influential upon the local politics.

Broadly put, the pattern of Islamism in South Sulawesi comprises at least three models of Islamism occurring both within the state or royal institutions (royal structural power) and outside the state or royal institutions. The pattern of Islamism within the governmental institutions (the structural government) includes: first, the patterns the Datuks who had been successful in convincing the regional kings in South

${ }^{10}$ The term "The Porch of Medina" has become an issue and a new term for people of South Sulawesi. Moreover, the term indicates that the region has some historical values as a solid Muslim community such as that of Aceh. 
Sulawesi to embrace Islam; second, the pattern of the Islamic parties that have been present since the era of the Old Order, such as Syarikat Islam, the Partai Persatuan Pembangunan (PPP), the Partai Keadilan Sejahtera (PKS) and the Partai Bulan Bintang (PBB). As for the pattern of Islamism existing outside the formal institutions of the government, it comprises: first, the pattern of Kahar Muzakkar, who set upon rebellion or resistance to the government with an objective of establishing Darul Islam, an Indonesian Muslim Army force (DI / TII); second, the pattern of the Committee of Preparation for Islamic Law Enforcement (KPPSI), which was considered partly successful in employing a structural politics approach; third, the pattern of Hizb at-Tahrir Indonesia (HTI), which has been consistent in preserving its struggle for establishment of Khilafah, as well as the patters of other Islamic movements that hold up the struggle for purification of Islam in accordance with their respective views of Islamism. ${ }^{11}$

From the elaboration of the patterns of Islamism above, it is clear that there are variants patterns of Islamism existing in the region of South Sulawesi. Islamism noticeably displays multi faces, and the variant can be seen from the activism of some Islamic movements that exist particularly in South Sulawesi. In addition to this, the variant is likewise observable in a structural power approach, more specifically in the government's political policies both at provincial and district levels with regards to the political ideology ideals of Islam that carries the formalization of the Islamic law in the governmental institutions in South Sulawesi.

The formalization of sharia movement and the struggle for establishment of an Islamic state is not a new subject in the community of South Sulawesi. Kahar Muzakkar is considered to be the leading figure that performed "jibad" for reinforcement of Islamic law as a form of rejection upon the removal of the seven words in the Jakarta Charter as well as

${ }^{11}$ Islamism (Islamic ideology movement) is noticeable in the context of Islamic parties and non political party Islamic movements. 
rejection against the influence of communism in South Sulawesi in early 1951's. The movement is well known as the movement of Darul Islam / Indonesian Muslim Army Force (DI / TII). A following movement is the struggle or movement of Islamic law enforcement performed by KPPSI. For KPPSI, the formal enforcement of Islamic law has to proceed through political propaganda and propaganda of politics along with education and jibad by means of constitution and democracy within the framework of the unitary state of Indonesian Republic. This movement aims to achieve formal legitimacy of the institutionalization of Islam in the form of legislation of Special Autonomy for Islamic Law Enforcement in South Sulawesi Province as a political house. In same line scholars, experts, leaders of the society as well as leaders of Islamic institutions fill up the political house with the rules, manhaj, and laws based on the Qur'an and As-Sunnah (the prophetic traditions) in order that the struggle proceeds simultaneously and collaboratively. The next most influential movement is Hizb at-Tahrir Indonesia (HTI). For HTI, Khilafah is a definite solution to the problems of the nation. Muslims have once lived under the system of Khilafah, which enforced the laws of the religion on all aspects of people's life and carried out dakwah (Islamic missionary) to the whole human race through jibad fi sabilillah, that a great number of liberations and victories took place. It was under this system of Khilafah that all Muslims' affairs were successfully brought together, and this is the system that will unite, safeguard, and protect Muslim community. ${ }^{12}$

The occurrence of the Islamic movements in South Sulawesi is sociologically present in a complex contexts and manifestations, both in terms of the inherent internal dynamics of the Muslims and the external structure of Indonesian society. There are certain sociological conditions that serve as

\footnotetext{
${ }^{12}$ Muhammad Rahmat Imdadun, Transmisi Gerakan Revivalisme Islam Timur Tengah ke Indonesia 1980-2002: Studi atas Gerakan Tarbiyah dan Hizbu Tahrir Indonesia, Masters' Thesis, UI, Jakarta, 2003. p. 76
} 
motivations and at the same time provide a fertile ground for the growth of Islamic movements that have a tendency to establish formalistic Islamization in a country with a legalformal, doctrinal, and militant characters. The presence of ideological Islamic movements as shown by HTI, Wahdah Islamiyah, KPPSI, and other groups supporting the formalization of Islamic law in South Sulawesi certainly raises questions on the part of the public relating to the basis underlying the emergence of the movements.

The face of Islamism engaging in both intra and extra parliamentary areas in South Sulawesi brings about specific tones on the local political constellation, either directly or indirectly. PKS and some other Islamic parties such as PPP and $\mathrm{PBB}$, which prefer to participate within the power structure, also contribute a unique color in their activism in the struggle for Islamic values. KPPSI and some other Islamic movement forces in the extra parliamentary region, which tend to be more cooperative with the government, also reflect its own color in their efforts for the employment of Islamic law. The case is quite different from that of Hizb at-Tahrir Indonesia, which is more likely to be consistent with the concept Khilafah and in such manner makes an impression of certain level of contradictions with the model of democracy existing at present.

Some methods of movement pay a serious attention relating to the movement patterns of some Islamist groups in South Sulawesi. Among these is the emergence of a massive movement pattern conducted through printed media, social media and real movements occurring in the midst of the society. An instance for this is HTI, which massively develops a movement pattern adopting a cell system within the community with its model of halaqah,and it specifically picks out colleges and campuses as its main base. The most massive movement is through social media such as Facebook, Line, Wahtsapp, BBM, blogspot, and the like that continue to be influential within the community. In terms of printed media, a number of HTI cadres also frequently write on local newspapers. The massive movement as shown by HTI is a proof that almost all lines have been optimally utilized by HTI to spread its Islamist ideas. 
Another Islamist movement to bring up is such as PKS, although at certain occasions it is often unwilling to confirm when the reality frequently pointed out that the On Campus Islamic Missionary (LDK) and KAMMI are parts of the organization that greatly support the movement, both in public elections and in every policy issued by the party. In terms of both public and private campuses in South Sulawesi, the movements and affiliations of KAMMI and LDK are very clear both inside and outside the campus. LDK and KAMMI are associations followed by young generation with militant inclination, and they are always on the move to wide spread their Islamist ideas.

The bottom line is that the movements demonstrated in public, especially those of HTI and PKS, reflect a quite open pattern in spite of their being categorized as Islamists. Moreover, they also open up spaces of compromise and negotiation with the local government. Compromise and negotiation is a pattern of movement that seeks to preserve the existence of these Islamist groups in society, more specifically within the framework of the Unitary State of the Republic of Indonesia (NKRI).

Such was also the case when the Islamist group Wahdah Islamiyah became a new force of the Islamic movement in South Sulawesi. Wahdah Islamiyah was born and originally formed in South Sulawesi. Its leader, Ustadz Zaitun Rasmin, who repeatedly appears on private TV broadcast every Sunday, is a proof showing that their movements have become more open, although so far Wahdah Islamiyah has been identified as a radical conservative movement promoting the issue of sharia and the importance of Muslim leaders in every opportunity. This public appearance of Wahdah Islamiyah leader is a form of acknowledgment by the government and the society upon the leader as an individual and upon the organization that he leads.

At least that Islamism in South Sulawesi with its movement patterns as described above is heading towards post Islamism, a more modern sort of movement. That is to say that most of the existing movements are more accommodative to the ruler or the government, except Hizb at-Tahrir (HTI), 
which is more consistent with its political base and vision compared to other ideological movements in South Sulawesi. The tendency of the shifting face of Islamism to post Islamism is more or less influenced by three main sources of influence and challenge, namely, the influence of the existing political system in Indonesia, the emergence of secular critics and the geo political factor.

With different characteristics and patterns of movements or thoughts mentioned above, it is difficult to clearly define the dividing line between the groups of peaceful Islamism and the radical Islamism. In this context, Greg Fealy believes that Islamism cannot be classified into a separate category and hence distinguish between "moderate" and "liberal" Muslims. ${ }^{13}$ In reality, Islamism is a set of borderless unity that makes the boundaries between Islamism and the "moderate Islam" blurred. In this case it can be said that the thought of the Islamists could easily stand side by side with that of the "moderate" Muslim concerning particular issues and get its echo among the mainstream Islamic organizations such as Muhammadiyah and Nahdlatul Ulama (NU). Despite their reputation as a "moderate" organization, some fractions of these organizations are sympathetic to the main agenda of the Islamists. This is the reason why sometimes the viewpoints of this organization are corresponding to those of the existing Islamist groups. ${ }^{14}$

On the other hand, in terms of differences in articulation the two manifestations of Islamism above have relatively similar characteristics. The main point is that they employ Islam as a reference for all activities they perform, and define themselves as being "Islamic". Furthermore, they also share a main objective, that is, to wide spread Islam at all levels

${ }^{13}$ Greg Fealy, Islamic Radicalism in Indonesia: The Faltering revival," Southeast Asian affairs 2004 (Singapore: Institute of Southeast Asian Studies, 2004), in Burhanuddin Muhtadi, Dilema PKS...,pp. 104121.

${ }^{14}$ Ibid., p. 105 
through the implementation of Islamic sharia. Although they agree upon the idea of Islamization of the state and the society, they hold different viewpoints concerning how the method of Islamization process should be implemented at a practical level. Although antagonism between the two sometimes appears on the surface, their different perspective in terms of method is usually understood as a minor diversity in the strive for the same objective: the implementation of Islamic sharia at all levels. The first manifestation of Islamism practices an intra parliamentary politics (taking part in the power system) as a means for Islamization of the state and the society, while the second manifestation of Islamism practices an extra parliamentary politics (outside of the power system) to strive for the same ambition in spite of their different choice of means.

Political expressions and political ideology of Islam in its various variants as described above will affect the methods used by the Islamic political activists, including those in South Sulawesi. In this case, the most significant issue to highlight is whether such political ideals of Islam should be pursued through formal political instruments by making use of political parties, the parliament, or the bureaucracy as a venue for political games. On the other hand, it is likewise significant to look at other means that are also possible to take up, for example by involving communities from different nongovernmental organizations or some religious and social organizations to facilitate the process of diversification of the political significance to occur. Even when political parties should be the choice of instruments to articulate the interests of Islam, should it be restricted to include only political parties that formally have Islamic social and "theological" origins, or, on the contrary, should it comprise the parties that are formally "not symbolized" with Islamic characteristic.

Islamic activism as in the above makes an interesting subject for further studies with regards to ideology or the thinking of Islamism in South Sulawesi, and more specifically on the subject of ideological movements. In Indonesia, the shifting paradigm in the political system from the New Order 
to the Reformation era would widely open the space for community political involvement. At least the study of phenomena that exist will aim to figure out a pattern of systematic relationship between the political system and the Islamic politics in South Sulawesi in terms of both history and movements. This is so in order that the practice experienced could bring about solutions to the difficulties that have been occurring so far and hence makes it possible to build a synthesis that allows both Islam and the state to carry on in a good harmony.

\section{Conclusion}

The above description reveals a number of essential points. First, the phenomenon of Islamic revival reflects an attempt of the Muslims to correct of their own history, which no longer corresponds to a glorious past and was also not able to deal with modern civilization (because of contact with the West and the entry of modern science and technology). Second, it should be understood that the encounter of Islam with the West with its modern tendency makes the Islamic Awakening movement in this case can be understood as a response or reaction to modernization. This modernization stream has to watch over and make sure that the values of modernization it is not contrary to the values of Islam. Third, that the phenomenon of Islamic Awakening movement also develops in the context of political domination of the West upon the Islamic world over the years. HTI, PKS, KPPSI, Wahdah Islamiyah and so forth, have displayed their activism in South Sulawesi in a literally open and tolerant way. This is the face of Islamism that seems to be in the direction of postIslamism.

The elaboration above encourage Muslims today to welcome the view perceiving that it would be much better if there are no longer worries or negative judgments upon subjects coming from outside, especially democratic thoughts. In the same manner, democracy, which so far has been defined as the sovereignty of the nation, should not be confronted with 
the sovereignty of God, for the nation people or the human being is also God's creature. As humans are creation of God, the sovereignty of mankind is God's gift to man in order to achieve appropriate and peaceful life. Humans have been granted with tremendous potential from God to perform their duties as a vicegerent on earth. For that reason, discussions about God's sovereignty in the dynamics of democracy nowadays are no longer relevant.

\section{BIBLIOGRAPHY}

Anthony Bubalo, Greg Fealy \& Whit Mason. 2012. Zealous Democrats: Islamism and Democracy in Egypt, Indonesia and Turkey. Trans. Syamsu sRijal, PKS dan Kembarannya; Bergiat jadi demokrat di Indonesia, Mesir dan Turki. Jakarta, Komunitas Bambu.

Arun Kundnani, Islamism and the Roots Of Liberal Rage, Race Class 2008, Vol. 50(2).

Bahtiar Effendi. (2001), Teologi Baru Politik Islam; Pertautan Agama, Negara dan Demokrasi”, Galang Press, Yogyakarta.

Burhan Ghalioun. 2010. Islamology Comes to the Aid of Islamism, Diogenes, 257: 120.

Burhanuddin Muhtadi. 2012. Dilema PKS; suara dan syariah. Jakarta: Gramedia.

Muhammad Rahmat Imdadun. 2003. Transmisi Gerakan Revivalisme Islam Timur Tengab ke Indonesia 1980-2002: Studi atas gerakan tarbiyah dan Hizbut Tabrir Indonesia. Tesis Master, Universitas Indonesia. 